\title{
Recent Advances in Elastin-Based Biomaterials
}

María Luisa Del Prado-Audelo ${ }^{1,2}$, Néstor Mendoza-Muñoz ${ }^{3}$, Lidia Escutia-Guadarrama ${ }^{4}$, David M. Giraldo-Gomez ${ }^{5,6}$, Maykel González-Torres ${ }^{7}$, Benjamín Florán ${ }^{8}$, Hernán Cortes ${ }^{9}$, Gerardo Leyva-Gómez ${ }^{1}$

${ }^{1}$ Departamento de Farmacia, Facultad de Química, Universidad Nacional Autónoma de México, Ciudad de México, 04510, Mexico. ${ }^{2}$ Escuela de Ingeniería y Ciencias, Departamento de Bioingeniería, Tecnológico de Monterrey, Campus Ciudad de México, Ciudad de México, 14380, Mexico. ${ }^{3}$ Facultad de Ciencias Químicas, Universidad de Colima, Colima, 28400, Mexico. ${ }^{4}$ Departamento de Física, Facultad de Ciencias, Universidad Nacional Autónoma de México, Ciudad de México, 04510, Mexico. ${ }^{5}$ Departamento de Biología Celular y Tisular, Facultad de Medicina, Universidad Nacional Autónoma de México, Ciudad de México, 04510, Mexico. ${ }^{6}$ Unidad de Microscopía, Facultad de Medicina, Universidad Nacional Autónoma de México, Ciudad de México, 04510, Mexico. ${ }^{7}$ CONACyT-Laboratorio de Biotecnología, Instituto Nacional de Rehabilitación Luis Guillermo Ibarra Ibarra, Ciudad de México, 14389, Mexico. ${ }^{8}$ Departamento de Fisiología, Biofísica \& Neurociencias, Centro de Investigación y de Estudios Avanzados del Instituto Politécnico Nacional, Ciudad de México, 07360, Mexico. ${ }^{9}$ Laboratorio de Medicina Genómica, Departamento de Genómica, Instituto Nacional de Rehabilitación Luis Guillermo Ibarra Ibarra, Ciudad de México, 14389, Mexico.

Received, June 23, 2020; Revised, July 23, 2020; Accepted, August 5, 2020; Published, August 13, 2020.

ABSTRACT - Elastin is one of the main components of the extracellular matrix; it provides resistance and elasticity to a variety of tissues and organs of the human body, besides participating in cellular signaling. In addition, elastinderived peptides are synthetic biopolymers with a similar conformation and structure to elastin, but these possess the advantage of solubility in aqueous mediums. Due to their biological activities and physicochemical properties, elastin and related peptides may be applied as biomaterials to develop diverse biomedical devices, including scaffolds, hydrogels, and drug delivery systems for tissue engineering. Likewise, the combination of elastin with natural or synthetic polymers has demonstrated to improve the mechanical properties of biomedical products and drug delivery systems. Here we comprehensively describe the physicochemical properties and physiological functions of elastin. Moreover, we offer an overview of the use of elastin and its derivative polymers as biomaterials to develop scaffolds and hydrogels for tissue engineering. Finally, we discuss some perspectives on the employment of these biopolymers to fabricate new biomedical products.

\section{INTRODUCTION}

The use of biomaterials for biomedical applications has progressively increased in the last years, and many biopolymers are growingly employed in the fabrication of hydrogels, scaffolds, and drug delivery systems (1-4). In this regard, the physicochemical and biological properties of some proteins and peptides render them a fascinating option in the development of biopharmaceutical products (5).

Particularly, elastin protein and its derivatives result of singular interest due to their biological activities. Elastin is a significant constituent of the extracellular matrix (ECM); it confers stretch, flexibility, and strength to organs and tissues such as skin, blood vessels, lung, bladder, ligaments, and cartilage (6). Moreover, different studies have shown that elastin participates in cell signaling, regulating processes such as wound healing and vascular morphogenesis (7-9).
Furthermore, elastin-like polypeptides are artificial polymers that mimic the structure and conformation of elastin; however, these are soluble in an aqueous medium (10). Its general structure is composed of a repetitive sequence Val-Pro-GlyXaa-Gly, where Xaa may be any amino acid, except proline. Due to their structure and properties, it is expected that elastin and its derivatives exhibit low toxicity and immunogenicity. Thus, elastin and elastin-like peptides possess a strong potential for biomedical purposes, including drug delivery (11-13), wound healing (14-16), and tissue engineering (1720).

In this review article, we perform a detailed description of the physicochemical properties and physiological functions of elastin. Furthermore, we provide a current outlook on the use of elastin and

Corresponding Author: Gerardo Leyva-Gómez, Departamento de Farmacia, Facultad de Química, Universidad Nacional Autónoma de México, Cd. Universitaria, Coyoacán, México 04510, Mexico; E-mail: leyva@quimica.unam.mx 
elastin-derivated polymers as biomaterials to develop scaffolds and hydrogels for tissue engineering. Lastly, we mention some perspectives on the utilization of these biomaterials for new biomedical approaches.

\section{Morphogenesis of elastin and elasticity}

The elastic fibers are found in the skin, lung, arteries, ligaments, vocal cords, and elastic cartilage. These fibers are structures that provide resilience, ability to length, and snap-back; these allow the tissue to stretch and recoil without loss of structure. They are constituted of two morphologically and chemically distinct components: elastin and microfibrils. Elastin is an insoluble ECM protein that forms the internal core of the elastic fibers; its protein precursor is the tropoelastin. On the other hand, the microfibrils are composed of a complex array of macromolecules, including the structural glycoproteins fibrillin-1, fibrillin-2, and microfibril-associated glycoprotein-1 (MAGP-1). The microfibrils serve as a scaffold for deposition, alignment, and assembly of tropoelastin monomers $(21,22)$. Structurally, elastic fibers are a biomaterial comprising mainly of two distinct parts, an inner core of amorphous cross-linked elastin $(\sim 90 \%)$ and an outer microfibrillar mantle (microfibrils). However, elastic-fiber-associated molecules are also present and play an essential role in the organization of these fibers.

The elastin fibers synthesis involves different and sophisticated processes (Figure 1), which begin with the intracellular transcription and translation of the tropoelastin. It is an approximately $60-70 \mathrm{kDa}$ protein, whose length depends on alternative splicing. Tropoelastin exists as a monomer in solution in two forms: an open globular molecule and a distended. It is secreted from diverse elastogenic cell types such as fibroblasts, endothelial cells, and smooth muscle cells (23-25). Following extensive splicing in the transcript, the mature tropoelastin mRNA is exported from the cell nucleus. The translation is carried out on the surface of the rough endoplasmic reticulum (rER); meanwhile, a signal polypeptide is formed and cleaved at the moment that the protein enters the rER lumen. Then, the protein is transported to the Golgi, traveling through the lumen. In the intracellular space, tropoelastin is likely to be chaperoned by an elastin binding protein (EBP) to prevent self-aggregation, as well as premature degradation (26). Likewise, the peptidyl-prolyl cis/trans isomerase, FKBP65, is also associated with tropoelastin during the secretory pathway (27). Subsequently, the complex composed by tropoelastin and EBP travel through the Golgi, and it is secreted to the extracellular space. Once secreted, the incorporation of tropoelastin into the elastic fiber begins. The EBP delivers the tropoelastin in the fiber formation site and returns to the endosomal compartments to be reassociated with lately synthesized tropoelastin. The delivered tropoelastin is deposited in the microfibrils, covalently interacting through fibrillin-1, this process is facilitated by calcium-dependent binding of MAGP-1 to multiple sites within tropoelastin. MAGP-1 binds to the Cterminal region of tropoelastin and stabilizes it before the enzymatic crosslinking. Thus, the C-terminal of tropoelastin is critical, playing a pivotal role in the deposition of the monomer into growing elastin polymer.

Tropoelastin crosslinking requires that the molecules be associated and aligned to facilitate the generation of crosslinks between closely spaced lysines. The molecular mechanism through which tropoelastin concentration and ordering occur is known as coacervation. Coacervation plays a crucial role in elastogenesis because the inhibition of this mechanism leads to a decrease in elastin formation (28). Coacervation is an endothermic and entropicallydriven process that involves the interactions between the hydrophobic domains, triggering destabilization of the clathrate-like water shielding these regions. Tropoelastin is soluble in solutions at low temperatures, and water forms a clathrate-like structure around its hydrophobic regions, keeping the protein unfolded. At increasing temperature, tropoelastin molecules begin to aggregate and order by interactions between hydrophobic domains; also, the clathrate water is disrupted, allowing the interaction of hydrophobic regions $(28,29)$. These regions are rich in non-polar amino acids, including valine, glycine, proline, and alanine, which are often arranged in repeats of three to six amino acids peptides, such as GVGVP, GGVP, and GVGVAP. The needed conditions for an optimal coacervation process of human tropoelastin are $37{ }^{\circ} \mathrm{C}, 150 \mathrm{mM} \mathrm{NaCl}$, and $\mathrm{pH}$ $7-8$; thus, the physiological environment of the ECM is adequate for this process.

After deposition and alignment, tropoelastin molecules are crosslinked into elastin via enzymatic reactions. This crosslinking is carried out by the action of the lysyl oxidase, a copper-dependent amine oxidase. This enzyme catalyzes the oxidative deamination of $\varepsilon$-amino groups on lysine residues within tropoelastin to form the $\alpha$-aminoadipic- $\delta$ semialdehyde, allysine. In this respect, allysine is the reactive precursor to a variety of inter- and 
intramolecular crosslinks found in elastin. The spontaneous condensation of lysin and allysine results in the formation of elastin-specific crosslinks named desmosines and isodesmosines, which play an essential role in elastic fibers. Furthermore, these crosslinks are stable in structure, conferring a high tough to the elastic fibers.

The mechanical study at the micro- and macromechanical levels of elastic fibers confirms its remarkable elastic and resilient properties. Concerning this, Aaron et al. (30) determined Young's modulus of single elastin fibers isolated from bovine ligamentum nuchae, values were found in the range of $0.4-1.2$ MPa. Similarly, Koenders et al. (31) determined
Young's modulus of elastic fibers in the presence and absence of fibrillin-microfibrils, the measurements were $0.90 \pm 0.23 \mathrm{MPa}$ and $0.79 \pm 0.17 \mathrm{MPa}$, respectively. At the macro mechanical level, studies in elastic fiber-rich tissue from the dog, sheep, and pig aorta determined Young's modulus to be in the range of $0.1-0.8 \mathrm{MPa}(31,32)$. However, the more outstanding mechanical property of elastin is the linear elastic extension $(103-150 \%)$, the largest of any known biological material (32). Several hypotheses have been proposed to explain the elastic properties of elastin, being hydration, and consequently, changes in entropy the basis for understanding its elastic behavior.

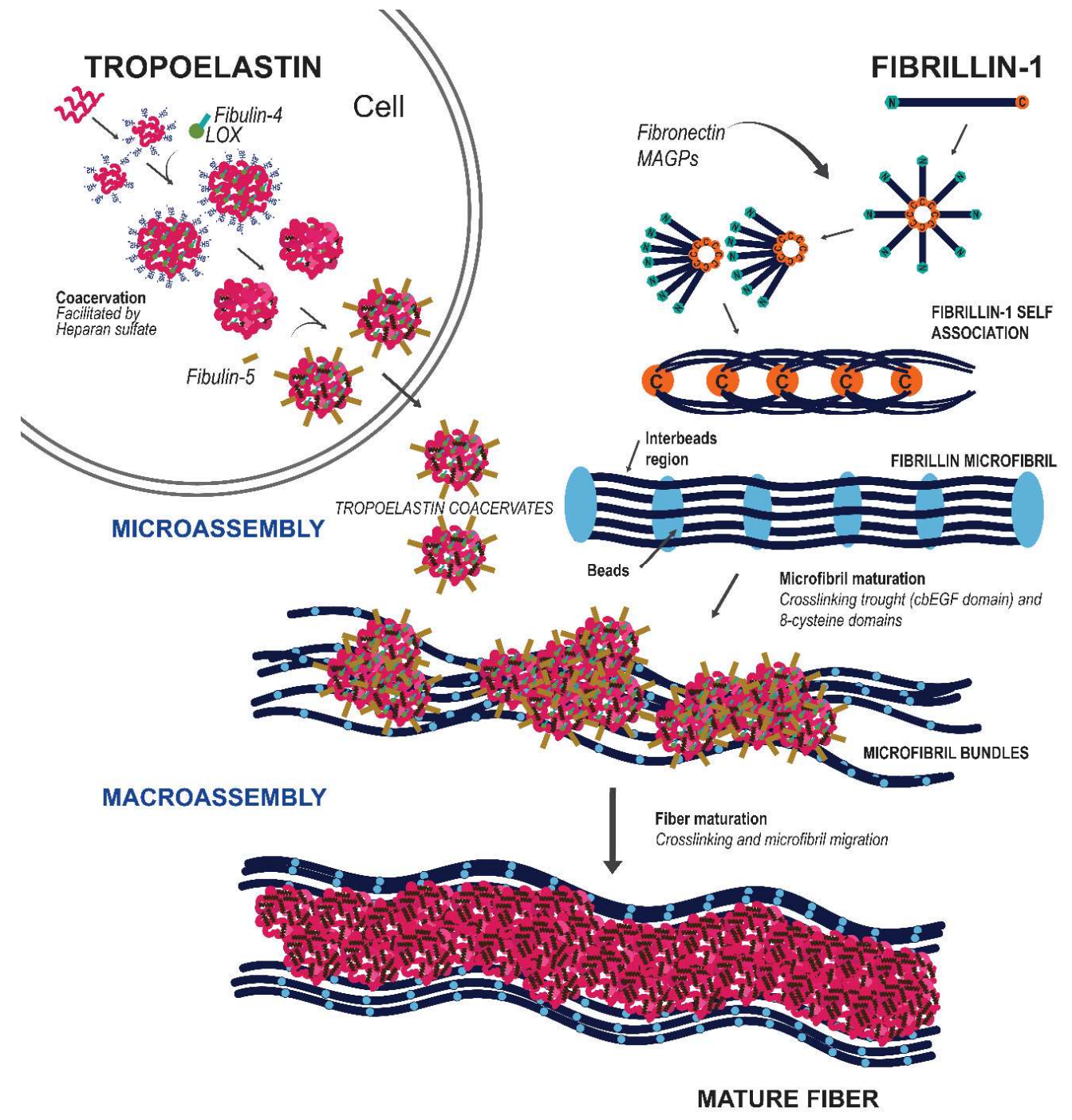

Figure 1. Diagram of the stages of elastic fiber formation. First, the micro-assembly of tropoelastin in coacervates and then, in aggregates released on the cell surface, whereas LOX associated with Fibulin-4 produces the initial crosslinking of tropoelastin. At the same time, Fibulin-5 helps in transport and fixation of the aggregates to microfibrils rich in fibrillin. Elsewhere, fibrillin1 assembles into multimers through C-terminal-N-terminal interactions and then into cross-linked supramolecular fibrils via cbEGF and 8-cysteine domains. The tropoelastin accumulates in the microfibrils providing a direct deposition of elastin. Finally, the macro-assembly is completed with the crosslinking of the tropoelastin mediated by LOX, to give rise to mature elastic fibers. 
The hydration of the polypeptide backbone of elastin is essential to keep the structural flexibility and grade of order (or disorder), considering the high percentage of non-polar amino acids in its structure. Li et al. (33) suggested that hydration in the hydrophobic domains is an essential source of the entropy-based elasticity of elastin. The changes in hydrophobic hydration of elastin tend to reorder itself to form a hydrophobic globule when it is held in its extended state, indicating that the hydrophobic effect also contributes to the holding process. On the other hand, restriction in the number of conformations available for the elastin due to the high elastin chain disorder opposes both stretching and tight packing (32).

\section{THE PHYSIOLOGICAL FUNCTION OF ELASTIN}

ECM molecules are relevant regulators of cellular function, and it is known that many types of diseases are strongly correlated with a disruption in ECM homeostasis (34). As previously mentioned, elastin is a vital constituent of the ECM that presents a specific chemical nature and strong crosslinking, making it a very stable molecule.

In physiological conditions such as growth, wound healing, and tissue remodeling during aging, several ECM components are degraded and have biological activity, for example, as chemoattractants or proinflammatory chemokines involved in signaling pathways. For this reason, they are termed matrikines (35). It has been demonstrated that matrikines can modulate essential cell functions such as cell proliferation, migration, invasion, protease production, and angiogenesis (36), either positively or negatively. In some cases, alterations in those functions suggest a relevant role of matrikines in the development of tumor invasion and metastasis (37). In particular, matrikines originated by a chemical or enzymatical degradation process of elastin, are known as elastin derived peptides (EDP) or elastokines (38). During physiological aging, there is an increment in the activity of enzymes that catalyze the process of elastin degradation; such enzymes are named elastases (39). Also, during several pathological and physiopathological conditions, elastases and other enzymes with elastase activity like several metalloproteinases (MMPs) (MMP-2, MMP-7, MMP9, and MMP-12) (40), are up-regulated, causing an increase in the number of released elastin peptides.

Since elastin cleavage is considered a pathological process, most studies have focused on investigating the adverse effects of EDP release (Figure 2). Nevertheless, it has also been shown that EDP also has an essential biological role in the human body (41), mainly in organs or tissues with high elastin content such as skin, arteries, and lungs, as well as in its interaction with the immune and nervous system (4245).

Biological activity of EDP is mediated by several cell surface receptors such as galectin- $3, \alpha_{v} \beta_{3}, \alpha_{v} \beta_{5}$ integrins, and its main receptor, the elastin receptor complex (ERC). The ERC is a heterotrimeric receptor (26) composed of a peripheral EBP subunit associated with the protective protein/cathepsin A (PPCA) and neuraminidase-1 (Neu-1), a membrane-associated protein. The EBP is the part of the complex that interacts with EDP and has a binding site for EDP and other for a galactosugar.

Once bound to EBP, EDP elicits the transduction of signals from the extracellular space to the cytoplasmic zone. Regarding this point, Duca et al. (46) demonstrated that EDP-EDP interaction stimulates the Neu-1 sialidase activity. Additionally, it was suggested that sialic acid residues cleaved from glycosugars and glycolipids act as second messengers, leading to the regulation of different signal transduction pathways in several cell types interacting with EDP.

Galactosugars (mainly lactose or chondroitin sulfate) are antagonists of EDP as they promote the release of EBP from the complex, inhibiting the biological effects of EDP-EBP interaction (47). Besides, Robinet et al. (48) reported that it is possible to block EDP binding onto EBP using the V14 peptide (VVGSPSAQDEASPL), which can trap elastin derived peptides, preventing its adverse effects. Likewise, deoxy-2,3-dehydro-N-acetylneuraminic acid (DANA) is another antagonist molecule that inhibits the sialidase activity of Neu-1, necessary for signal transduction (46). Interestingly, Neu-1 activation involves signaling events such as the activation of phosphoinositide-3-kinase $\gamma$ (PI3K $\gamma$ ) pathway related to atherosclerosis. In this inflammatory disease, foam cells (lipid-laden macrophages) contribute to plaque formation within the artery wall (49). CD36 receptor is also modulated by Neu-1, which activates an intracellular signaling cascade that increases the uptake of oxLDL by macrophages, thus, contributing to atherosclerotic plaque formation (50). 


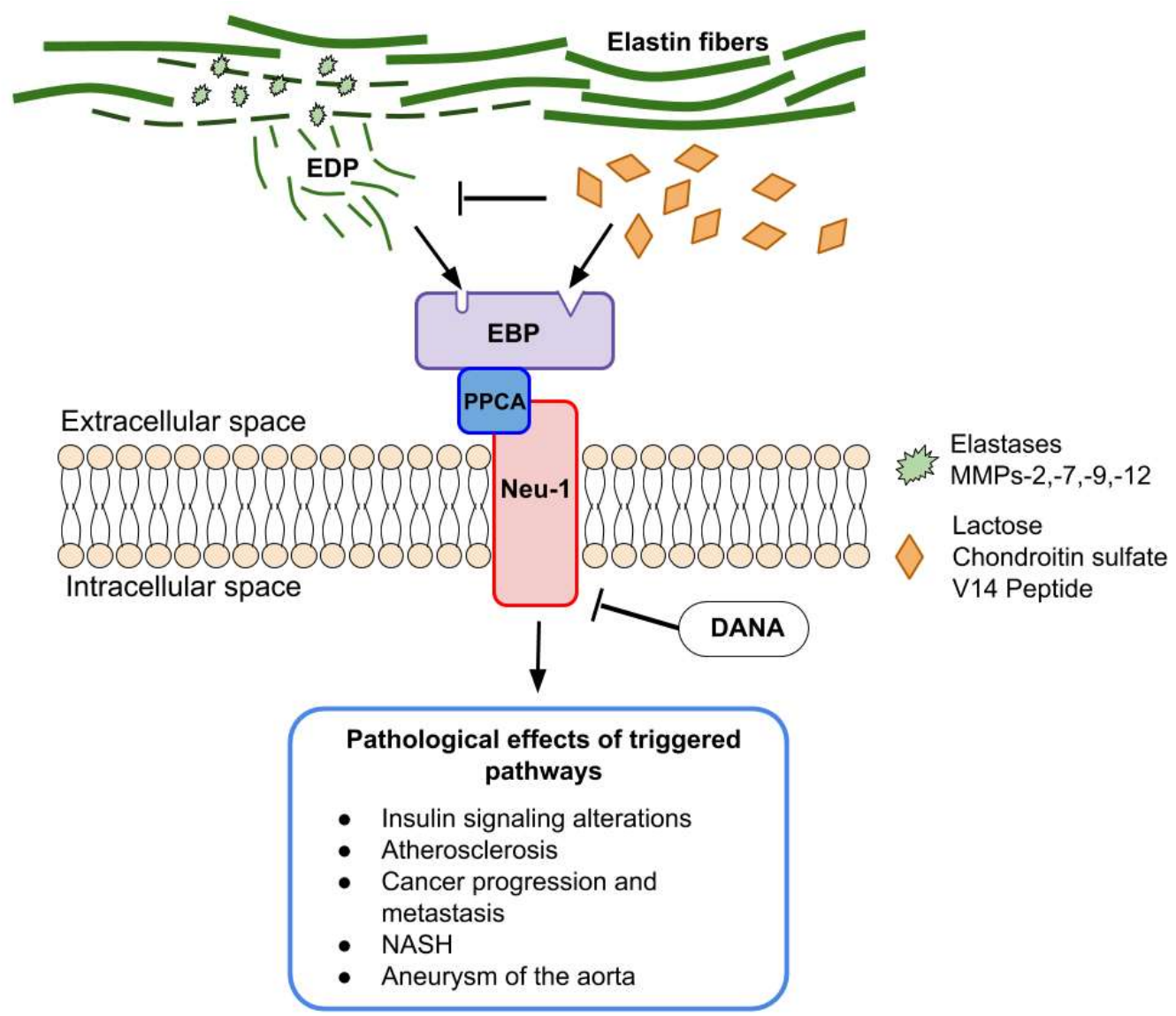

Figure 2. Pathological role of elastin derived peptides (EDP). Elastin is cleaved by elastases and matrix metalloproteinases (MMPs) during either physiological or pathophysiological aging, producing EDP. Binding of these peptides to the elastin receptor complex (ERC) triggers several signaling pathways modulated by Neuraminidase-1 (Neu-1) sialidase activity. Various of the activated signaling events have an important role in the development of pathological conditions. Lactose, chondroitin sulfate, V14 peptide, and deoxy-2,3-dehydro-N-acetylneuraminic acid (DANA) inhibit the effects of the interaction between EDP and ERC. EBP, elastin binding protein; PPCA, protective protein/cathepsin A; NASH, non-alcoholic steatohepatitis.

EDPs have been shown as regulators of insulin resistance development (51), chemotactic attractors to cancer cells (52), and contributors to lipid accumulation in hepatocytes in patients with nonalcoholic steatohepatitis (NASH) (53). It has been demonstrated that, besides physiological aging, several genetic alterations also lead to connective tissue disorders related to elastin degradation. Marfan syndrome is an example of a heritable disorder linked to mutations in fibrillin genes (fibrillin-1 is the main component of the microfibrils in which tropoelastin is deposited and crosslinked to form elastic fibers). Some patients also presented an up-regulation of MMP-1, MMP-2, MMP-3, and MMP-9, implicated in the cleavage of fibrillin-1 (54). This disease may be lifethreatening because of its manifestations in the cardiovascular system. One of the most common is aneurysm formation, having aortic wall rupture as a consequence (55). Finally, due to all physiological and pathophysiological implications of EDP, these peptides are suggested as biomarkers of the progression of diseases that, in certain stages, could be lethal. Therefore, the development of therapeutic alternatives in which EDP adverse effects may be, at least, partially reduced, is of great interest.

\section{ELASTIN-BASED BIOMATERIALS}

The growing interest in elastin as a biomaterial is due to its properties of elasticity, self-assembly, long-term stability, and biological activity. Notably, the attributes of elasticity and biological activity of elastin in combination with natural or synthetic polymers are utilized to model and improve the mechanical properties of biomedical products and drug delivery systems. 


\section{Elastin-based cell scaffolds}

The exceptional properties of elastin make it an attractive candidate for a range of tissue-engineering applications. Many autografts, allografts, and xenografts contain elastic fibers. Well-known examples are split-skin autografts for burn wounds (56), autologous blood vessels allografts for coronary graft reconstruction (57), and aortic heart valve xenografts (58). Biofabrication methodologies provide access to numerous variants from elastin-based cellscaffolds. Therefore, elastin-mimetic protein polymers represent suitable candidates for use as scaffolding materials in tissue engineering, in which critical properties such as mechanical response, cell-scaffold interactions, and biodegradability may be controlled through modification of the biomaterial properties.

\section{Decellularized cell scaffolds containing elastin}

Decellularization is defined as a process to obtain natural matrices frequently used as scaffolds to replace tissues and organs. This process implies the removal of the allogeneic or xenogeneic antigens from cells in the source tissue or organ that lead to an immune response in the host body $(59,60)$. Thus, decellularization produces a natural three-dimensional scaffold containing the main elements of the ECM, which can be repopulated with host cells (61). One of

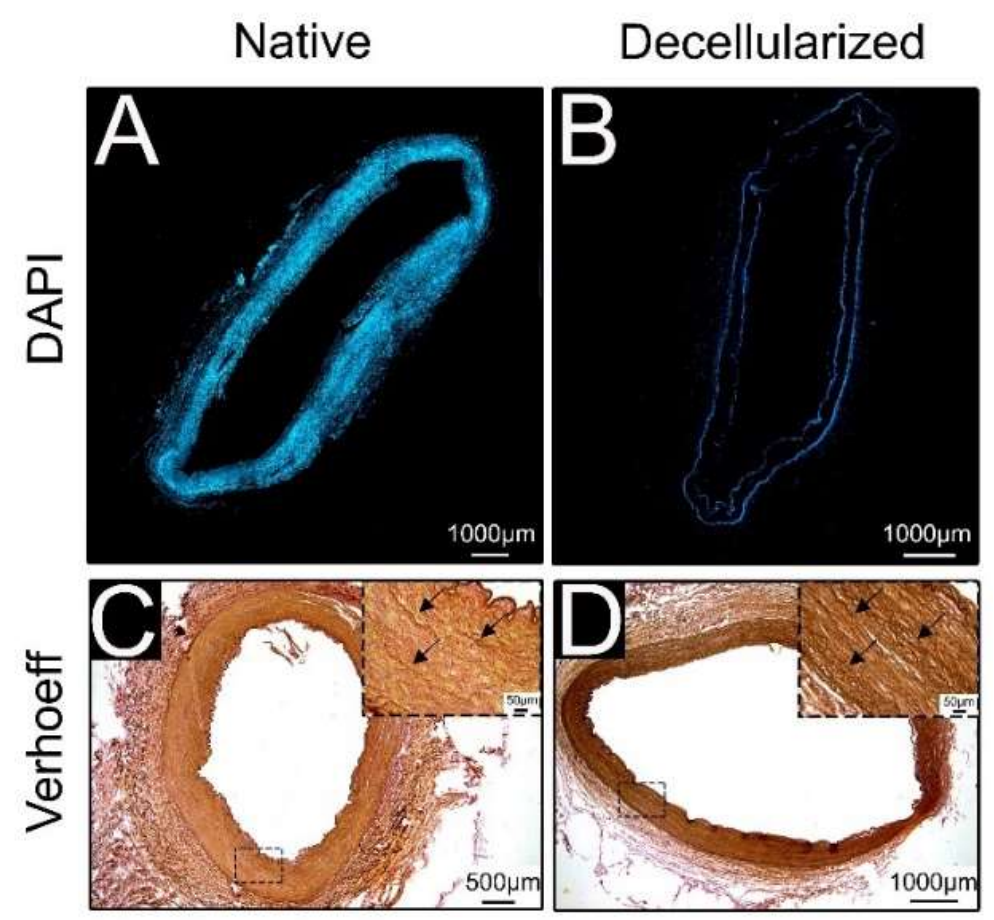

Figure 3. Elastin-based scaffold obtained by the perfusion decellularization process (human artery). The method removes the cells in the native ECM (A), leaving a scaffold without cells (B). The process retains essential fibrous protein like elastin (D). The arrows show the preservation of elastin from native tissue (C) to the decellularized matrix (D). preservation of native architecture of the source tissue or organ in contrast to purified-component processes, e.g., we have obtained a human-decellularized artery with well-preserved elastin (Figure 3). However, some approaches had used decellularization to get a bio-ink for the $3 \mathrm{D}$ manufacturing process, disrupting the native architecture, and taking advantage of the biochemical composition and biological cues of the ECM. Nevertheless, it is challenging to retain allnatural components of the ECM (62).

On the other hand, this process has some unsolved challenges, such as the hazard of incomplete decellularization or the uncontrollable variability in the attributes of the final matrix (59). Thus, decellularization is performed with a wide variety of intricated protocols, using diverse decellularization agents (physical, chemical, and biological) such as detergents (e.g., Sodium deoxycholate, SDS) and enzymes (e.g., trypsin) (63). However, decellularization by SDS or trypsin could change the ECM composition (63). Finally, it is difficult to compare results obtained from different approaches since each protocol will result in its own set of residual ECM components. Besides, it is unknown which molecule causes a specific effect due to the complex composition of the ECM.

\section{the main advantages of decellularized matrices is the}


Purified elastin cell scaffolds

Purification of a target protein is essential when are necessary all effects of mature extracellular elastin in fibrous form. In this respect, due to the intermolecular cross-links in elastin, the protein is highly insoluble, and it can only be dissolved hydrolyzing some peptide bonds, which may lead to degradation of the final properties of the purified product. Thus, this insolubility is often used for isolation of elastin from tissues. Sources rich in insoluble elastin include bovine and equine ligaments because that protein comprises a high percentage of its dry weight. Another standard method to obtain elastin-mimetic biomaterials is a phase transition, which may be applied for purification recombinant proteins as fusions to the elastin sequence (64). This technique has the advantage over sophisticated chromatographic techniques that the purification can be achieved through the relatively benign method of inverse temperature cycling, which can provide high purity fusions (65).

\section{Scaffolds}

One of the predominant applications of elastin in tissue engineering is as a 3D scaffold to biomimetize tissues (Table 1). The combination of elastin with collagen is one of the most frequent strategies to simulate the ECM of soft tissues. The type of interaction of both proteins can start from a simple approach such as blending and casting at room temperature or freezedrying to induce crosslinking, until the use of crosslinkers such as genipin, or via the 1-Ethyl-3-(3dimethylaminopropyl)carbodiimide/N-

hydroxysuccinimide (EDC/NHS) route (66). For scaffolds that require a higher mechanical response, stability, and resistance to degradation, chemical crosslinking is a suitable alternative to improve their performance (67). Although the freeze-drying technique induces pore formation during the sublimation process, the control of tortuosity can be increased and enhanced by injection of $\mathrm{CO}_{2}$ at controlled pressure and temperature (68).

The cellular response of elastin-collagen scaffolds is usually governed by the protein that predominates in concentration. Generally, these types of structures have excellent biocompatibility, favoring cell proliferation, and acting as a high-quality ECM alternative. Because elastin exhibits biological properties, the proposals where it is used as a scaffolding coating agent to promote cell induction are also attractive. Even the combination strategy of elastin with poly- $\varepsilon$-caprolactone (PCL) exhibits suitable applications in tissue engineering. Considering that PCL is a polymer widely known for its medical applications, it favors the acceptance of the resulting elastin scaffolds, in addition to reducing the cost of the final product and exhibiting better mechanical properties (69). In general, scaffolds from elastin, among other aspects of practicality and accessibility, seek to increase the robustness of biomaterials in tissue engineering, in contrast to the low reproducibility of decellularized tissues.

\section{Electrospinning}

The use of electrospinning allows us to have small diameter fibers. Depending on the diameter and length of the fiber, it is possible to modulate the elastic response. The collection of fibers allows different types of orientation to confer diverse geometries that may favor cell infiltration. One electrospinning feature is pore size control, similar to Bottom-up constructs in the nanotechnology area (70). Furthermore, the set of fibers or mesh may have a subsequent surface functionalization, the interior of the fibers may contain a drug or protein, and the sum of the functional factors confers a high potential for application to this technique. The predominant compositions are elastin with collagen, or sometimes with PCL. While crosslinking after fiber formation via EDC/NHS is a common strategy to confer adequate mechanical properties (71). The elastin-collagen mesh from electrospinning can be deposited in its formation on an implant tube to favor its grafting. Other scaffolding structures consist of double or triple layers of interlocked mesh (71). Even though electrospinning is a technique that is not recent, its peak is evident in literature today. As with traditional scaffolds, there is little exploration of other polymers for medical use to confer adequate mechanical properties and improved cellular compatibility.

\section{Hydrogels}

The manufacture of hydrogels for tissue engineering has been aimed at non-specific applications in most cases, with descriptions of mechanical resistance rather than cellular interaction. Hydrogels may function as a scaffold, exhibiting a biological response; it can be applied as a reservoir for the controlled release of drugs or proteins that affect the cell lines of interest (72). Besides, they can present a response to external stimuli such as changes in viscosity as a function of temperature variation. These aspects facilitate injection into anatomical regions and subsequent gelling as a tissue engineering scaffold. 
The composition that has predominated is collagen and elastin to simulate ECM. Since elastin or collagen alone does not offer an increased stiffness to hydrogels, in almost all studies, a chemical crosslinking is employed to generate covalent bonds that allow greater rigidity and structural support in cell seeding (73). The control of pore formation is crucial, as with scaffolds and nanofiber formation. In this regard, the $\mathrm{CO}_{2}$ injection at controlled pressure and temperature is an attractive strategy.
Some limitations to consider in the use of elastin as a biomaterial is its low solubility in water, the possible nucleation for calcification in tissues, and supplier quality controls to offer a sample with specific physicochemical properties. However, the use of elastin in biomaterials is attractive due to its mechanical resistance and biological response, which has allowed the biomimetization of scaffolds for tissue engineering.

Table 1. Selected examples of elastin biomaterials for tissue engineering

\begin{tabular}{|c|c|c|c|c|c|}
\hline Protein & Polymer & Interaction & Application & Evaluation & Reference \\
\hline \multicolumn{6}{|c|}{ SCAFFOLD } \\
\hline Bovine elastin & $\begin{array}{l}\text { Bovine } \\
\text { type I } \\
\text { collagen }\end{array}$ & $\begin{array}{l}\text { Blended and } \\
\text { crosslinked with } \\
\text { 1,4-butanediol } \\
\text { diglycidyl ether }\end{array}$ & $\begin{array}{l}\text { Extrahepatic } \\
\text { transplantation }\end{array}$ & $\begin{array}{l}\text { Promotion of angiogenesis and } \\
\text { ECM deposition. Preserving } \\
\text { the integrity, viability, and } \\
\text { function of the islet. }\end{array}$ & (74) \\
\hline Bovine elastin & $\begin{array}{l}\text { Bovine } \\
\text { type I } \\
\text { collagen }\end{array}$ & $\begin{array}{l}\text { Blended and } \\
\text { lyophilized }\end{array}$ & Heart valve & $\begin{array}{lrr}\text { Bi-layer } & \text { scaffold } & \text { with } \\
\text { anisotropic } & \text { bending } & \text { moduli } \\
\text { with adequate cell distribution. }\end{array}$ & $(75)$ \\
\hline Elastin & $\begin{array}{l}\text { Type I } \\
\text { collagen }\end{array}$ & $\begin{array}{l}\text { Blended and } \\
\text { crosslinked with } \\
\text { 1,4-butanediol } \\
\text { diglycidyl ether }\end{array}$ & $\begin{array}{l}\text { Biomimetic } \\
\text { collagen/elastin meshes } \\
\text { for ventral hernia }\end{array}$ & $\begin{array}{l}\text { Biomechanical effect for } \\
\text { hernia repair, increased tissue } \\
\text { restoration, } \\
\text { neovascularization, and gene } \\
\text { expression associated with de } \\
\text { novo matrix deposition, } \\
\text { angiogenesis, adipogenesis, } \\
\text { and skeletal muscles. }\end{array}$ & (67) \\
\hline Bovine elastin & $\begin{array}{l}\text { Bovine } \\
\text { type I } \\
\text { collagen }\end{array}$ & Blended & $\begin{array}{l}\text { Promote the cellular } \\
\text { interaction } \\
\text { composites }\end{array}$ & $\begin{array}{l}\text { The predominant cellular } \\
\text { interaction is due to the protein } \\
\text { in the larger composition. }\end{array}$ & (76) \\
\hline Equine elastin & $\begin{array}{l}\text { Bovine } \\
\text { type I } \\
\text { collagen }\end{array}$ & $\begin{array}{lr}\text { Casting, } & \text { heparin- } \\
\text { EDC/NHS } & \text { cross- } \\
\text { linking, freezing } & \text { frore-drying } \\
\text { and freeze }\end{array}$ & $\begin{array}{l}\text { Vascular grafts } \\
\text { resembling the native } \\
\text { blood vessel }\end{array}$ & Practical use in anastomosis. & (66) \\
\hline Bovine elastin & $\begin{array}{l}\text { Bovine } \\
\text { type I } \\
\text { collagen }\end{array}$ & $\begin{array}{l}\text { Blended and freeze- } \\
\text { drying }\end{array}$ & $\begin{array}{l}\text { Biomimetic scaffold for } \\
\text { cardiovascular tissue } \\
\text { engineering }\end{array}$ & $\begin{array}{l}\text { Modulation of smooth muscle } \\
\text { cells towards a contractile state } \\
\text { via reduced proliferation and } \\
\text { increase of } \alpha \text {-SMA. }\end{array}$ & (77) \\
\hline Bovine elastin & $\begin{array}{l}\text { Bovine } \\
\text { type I } \\
\text { collagen }\end{array}$ & $\begin{array}{l}\text { EDC/NHS cross- } \\
\text { linking and freeze- } \\
\text { drying }\end{array}$ & $\begin{array}{l}\text { Scaffold for soft tissue } \\
\text { engineering }\end{array}$ & $\begin{array}{l}\text { Structural stability, strength, } \\
\text { and degradation resistance. } \\
\text { Highly porous structures were } \\
\text { able to support cell infiltration } \\
\text { and growth. }\end{array}$ & (78) \\
\hline Bovine elastin & $\begin{array}{l}\text { Silk } \\
\text { fibroin }\end{array}$ & $\begin{array}{l}\text { Blended, } \\
\text { crosslinked with } \\
\text { genipin, and freeze- } \\
\text { drying }\end{array}$ & Wound dressing & $\begin{array}{l}\text { Adequate re-epithelialization } \\
\text { and the fastest wound closure. }\end{array}$ & (79) \\
\hline Equine elastin & $\begin{array}{l}\text { Bovine } \\
\text { type I } \\
\text { collagen, } \\
\text { chondroiti } \\
\text { n sulfate }\end{array}$ & $\begin{array}{l}\text { EDC/NHS cross- } \\
\text { linking and freeze- } \\
\text { drying }\end{array}$ & $\begin{array}{l}\text { Scaffolds for tissue } \\
\text { engineering }\end{array}$ & $\begin{array}{l}\text { Adequate mechanical } \\
\text { resistance and elasticity. }\end{array}$ & $(80)$ \\
\hline
\end{tabular}


TABLE 1 Continued

\begin{tabular}{|c|c|c|c|c|c|}
\hline Equine elastin & $\begin{array}{l}\text { Bovine } \\
\text { type I } \\
\text { collagen }\end{array}$ & $\begin{array}{l}\text { EDC/NHS cross- } \\
\text { linking }\end{array}$ & $\begin{array}{l}\text { Scaffolds for tissue } \\
\text { engineering }\end{array}$ & $\begin{array}{l}\text { Decrease in the calcification } \\
\text { phenomenon associated with } \\
\text { the presence of elastin in the } \\
\text { scaffold. }\end{array}$ & $(81)$ \\
\hline Bovine elastin & $\begin{array}{l}\text { Polyethyle } \\
\text { ne } \\
\text { oxide/chiti } \\
\text { n/chitosan } \\
\text { matrix }\end{array}$ & $\begin{array}{l}\text { Crosslinked with } \\
\text { genipin }\end{array}$ & $\begin{array}{l}\text { Cartilage } \\
\text { engineering }\end{array}$ & $\begin{array}{l}\text { Induces a high amount of } \\
\text { regenerated bovine knee } \\
\text { chondrocytes, } \\
\text { glycosaminoglycans, and type } \\
\text { II collagen; all these are } \\
\text { cartilaginous components. }\end{array}$ & $(82)$ \\
\hline Bovine elastin & $\begin{array}{l}\text { Polyethyle } \\
\text { ne } \\
\text { oxide/chiti } \\
\text { n/chitosan } \\
\text { matrix }\end{array}$ & $\begin{array}{l}\text { Crosslinked with } \\
\text { genipin }\end{array}$ & $\begin{array}{l}\text { Cartilage } \\
\text { engineering }\end{array}$ & $\begin{array}{l}\text { Adequate cryopreservation, } \\
\text { synthesis of } \\
\text { glycosaminoglycans and } \\
\text { collagen, high proliferation of } \\
\text { chondrocytes. }\end{array}$ & $(83)$ \\
\hline $\begin{array}{l}\text { Bovine elastin, } \\
\text { human serum } \\
\text { albumin, and } \\
\text { poly-L-lysine }\end{array}$ & $\begin{array}{l}\text { Chitosan } / \gamma \\
\text { - } \\
\text { poly(gluta } \\
\text { mic acid) } \\
\text { scaffold } \\
\end{array}$ & $\begin{array}{l}\text { Blended and surface } \\
\text { crosslinked with } \\
\text { genipin }\end{array}$ & $\begin{array}{l}\text { Cartilage } \\
\text { engineering }\end{array}$ & $\begin{array}{l}\text { Promotes the growth of } \\
\text { chondrocytes, secrete ECM } \\
\text { and improve the } \\
\text { regenerative ability of } \\
\text { cartilaginous tissues. }\end{array}$ & $(84)$ \\
\hline Bovine elastin & PCL & Blended & 3D composite & Highly porous foam. & $(68)$ \\
\hline Bovine elastin & PCL & $\begin{array}{l}\text { Crosslinked with } \\
\text { glutaraldehyde }\end{array}$ & 3D composite & $\begin{array}{l}\text { High porous elastic scaffold } \\
\text { with high swelling capacity. } \\
\text { The 3D structure support } \\
\text { primary articular cartilage } \\
\text { chondrocyte adhesion and } \\
\text { proliferation }\end{array}$ & $(69)$ \\
\hline
\end{tabular}

\section{ELECTROSPINNING}

\begin{tabular}{|c|c|c|c|c|c|}
\hline Bovine elastin & $\begin{array}{l}\text { Collagen } \\
\text { type I } \\
\text { from } \\
\text { calfskin } \\
\end{array}$ & $\begin{array}{l}\text { Blended, } \\
\text { electrospinning, and } \\
\text { EDC/NHS cross- } \\
\text { linking }\end{array}$ & $\begin{array}{l}\text { Mesh for tissue } \\
\text { engineering }\end{array}$ & $\begin{array}{l}\text { Growth of smooth muscle cells } \\
\text { as a confluent layer after } 14 \mathrm{~d} \\
\text { of culture. }\end{array}$ & (70) \\
\hline Bovine elastin & $\begin{array}{l}\text { Bovine } \\
\text { type I } \\
\text { collagen, } \\
\text { silk } \\
\text { fibroin, } \\
\text { and PCL } \\
\end{array}$ & $\begin{array}{l}\text { Blended, } \\
\text { electrospinning, and } \\
\text { EDC/NHS cross- } \\
\text { linking }\end{array}$ & $\begin{array}{l}\text { Tri-layered arterial } \\
\text { grafts }\end{array}$ & $\begin{array}{l}\text { Burst strength adequate and } \\
\text { four-week degradation in vitro }\end{array}$ & (71) \\
\hline Bovine elastin & $\begin{array}{l}\text { Rat } \\
\text { collagen } \\
\text { type I, } \\
\text { PCL }\end{array}$ & Electrospinning & $\begin{array}{l}\text { Dermal substitute } \\
\text { scaffold }\end{array}$ & $\begin{array}{l}\text { Low stiffness and high } \\
\text { elasticity. Promotion of } \\
\text { keratinocyte and fibroblast } \\
\text { proliferation, } \\
\text { integration, and accelerated } \\
\text { angiogenesis. }\end{array}$ & $(85)$ \\
\hline Bovine elastin & $\begin{array}{l}\text { Bovine } \\
\text { type I } \\
\text { collagen, } \\
\text { PCL }\end{array}$ & $\begin{array}{l}\text { Blended, } \\
\text { electrospinning, and } \\
\text { EDC cross-linking }\end{array}$ & $\begin{array}{l}\text { Three-layered matrix to } \\
\text { mimic the arterial } \\
\text { architecture }\end{array}$ & $\begin{array}{l}\text { Similar mechanical response } \\
\text { as a native artery. }\end{array}$ & $(86)$ \\
\hline
\end{tabular}


TABLE 1 Continued...

\begin{tabular}{|c|c|c|c|c|c|}
\hline Elastin & $\begin{array}{l}\text { Collagen } \\
\text { hydrolysat } \\
\text { e type I } \\
\text { and III, } \\
\text { PCL } \\
\text { functional } \\
\text { ized }\end{array}$ & Electrospinning & $\begin{array}{l}\text { Scaffolds for tissue } \\
\text { engineering }\end{array}$ & $\begin{array}{l}\text { Morphological stability and } \\
\text { good water uptake. }\end{array}$ & (87) \\
\hline rhT & PCL & Electrospinning & $\begin{array}{l}\text { Synthetic vascular } \\
\text { conduit }\end{array}$ & $\begin{array}{l}\text { Mechanical properties } \\
\text { optimized, permeability, } \\
\text { compliance, elastic modulus, } \\
\text { burst pressure. }\end{array}$ & (88) \\
\hline Elastin & PLGA & $\begin{array}{l}\text { Blended, } \\
\text { electrospinning }\end{array}$ & $\begin{array}{l}\text { Salivary gland tissue } \\
\text { regeneration }\end{array}$ & $\begin{array}{l}\text { High modulus of elasticity } \\
\text { with apicobasal polarization of } \\
\text { salivary gland epithelial cells. }\end{array}$ & (89) \\
\hline Bovine elastin & $\begin{array}{l}\text { Polydioxa } \\
\text { none }\end{array}$ & Electrospun blend & Bioresorbable scaffolds & $\begin{array}{l}\text { Minimal effects in innate and } \\
\text { acquired immune response } \\
\text { assays. }\end{array}$ & $(90)$ \\
\hline Bovine elastin & $\begin{array}{l}\text { Polydioxa } \\
\text { none }\end{array}$ & $\begin{array}{l}\text { Cross-linking of } \\
\text { electrospun elastin } \\
\text { on tubes of } \\
\text { polydioxanone } \\
\text { blended with } \\
\text { soluble elastin }\end{array}$ & $\begin{array}{ll}\text { Vascular } & \text { tissue } \\
\text { engineering }\end{array}$ & $\begin{array}{l}\text { High systolic pressure, similar } \\
\text { to the native artery. Ideal for } \\
\text { replacement applications. }\end{array}$ & (91) \\
\hline rHT & $\begin{array}{l}\text { Bis- } \\
\text { sulfosucci } \\
\text { nimidyl } \\
\text { and } \\
\text { glutaralde } \\
\text { hyde as } \\
\text { cross- } \\
\text { linkers } \\
\end{array}$ & $\begin{array}{l}\text { Electrospinning on } \\
\text { hydrogel }\end{array}$ & $\begin{array}{l}\text { Dermal substitute } \\
\text { scaffold }\end{array}$ & $\begin{array}{l}\text { Fibroblasts attached and } \\
\text { proliferated for at least } 14 \text { days } \\
\text { and deposited fibronectin and } \\
\text { collagen type I. }\end{array}$ & $(92)$ \\
\hline rHT & - & $\begin{array}{l}\text { Electrospinning and } \\
\text { cross-linking with } \\
\text { glutaraldehyde }\end{array}$ & $\begin{array}{l}\text { Dermal } \\
\text { engineering }\end{array}$ & $\begin{array}{l}\text { Suitable elastic module with } \\
\text { high porosity to promote cell } \\
\text { persistence. Induction de novo } \\
\text { collagen synthesis and } \\
\text { angiogenesis. }\end{array}$ & (93) \\
\hline
\end{tabular}

\section{HYDROGEL}

\begin{tabular}{|c|c|c|c|c|c|}
\hline Porcine elastin & $\begin{array}{l}\text { Rat } \\
\text { collagen }\end{array}$ & $\begin{array}{l}\text { Crosslinked } \\
\text { hydrogel } \quad \text { with } \\
\text { squaric acid }\end{array}$ & $\begin{array}{l}\text { Hydrogel for tissue } \\
\text { engineering }\end{array}$ & $\begin{array}{l}\text { Stiffer hydrogel and more } \\
\text { resistant to enzymatic } \\
\text { degradation. }\end{array}$ & (73) \\
\hline Bovine elastin & $\begin{array}{l}\text { Rat type-I } \\
\text { collagen }\end{array}$ & Blended & Lung tissue engineering & $\begin{array}{l}\text { Stiffness equal to the } \\
\text { theoretical value for a single } \\
\text { alveolar wall. Lung fibroblast } \\
\text { adhered to the hydrogel. }\end{array}$ & (94) \\
\hline
\end{tabular}


TABLE 1. Continued....

\begin{tabular}{|c|c|c|c|c|c|}
\hline Bovine elastin & $\begin{array}{l}\text { Hyaluroni } \\
\mathrm{c} \text { acid } \\
\text { functional } \\
\text { ized with } \\
\text { ethylenedi } \\
\text { amine and } \\
\text { ethylene } \\
\text { glycol } \\
\text { diglycidyl } \\
\text { ether }\end{array}$ & $\begin{array}{l}\text { Crosslinked } \\
\text { hydrogel }\end{array}$ & $\begin{array}{l}\text { Dermal and vascular } \\
\text { tissue engineering }\end{array}$ & $\begin{array}{l}\text { Adequate swelling capacity, } \\
\text { improved attachment, } \\
\text { viability, and proliferation of } \\
\text { dermal fibroblasts. }\end{array}$ & (95) \\
\hline Bovine elastin & rHT & $\begin{array}{l}\text { Crosslinked } \\
\text { hydrogel with } \\
\text { glutaraldehyde }\end{array}$ & Hybrid hydrogels & $\begin{array}{l}\text { Adequate mechanical } \\
\text { properties, high porosity that } \\
\text { allowed the migration of } \\
\text { human skin fibroblast cells. }\end{array}$ & (96) \\
\hline Bovine elastin & $\begin{array}{l}\text { Hyaluroni } \\
\text { c acid, } \\
\text { HA-EDA- } \\
\text { g- } \alpha- \\
\text { elastin }\end{array}$ & $\begin{array}{l}\text { Crosslinked } \\
\text { hydrogel } \quad \text { with } \\
\text { EDC/NHS }\end{array}$ & $\begin{array}{l}\text { 3D culture of vascular } \\
\text { endothelial cells }\end{array}$ & $\begin{array}{l}\text { Control release of vascular } \\
\text { endothelial growth factor, } \\
\text { proliferation of human } \\
\text { vascular endothelial cells and } \\
\text { formation of tubular structures. }\end{array}$ & $(72)$ \\
\hline Bovine elastin & Alginate & $\begin{array}{l}\text { Crosslinked } \\
\text { hydrogel and films } \\
\text { with calcium } \\
\text { chloride }\end{array}$ & $\begin{array}{l}\text { Hydrogel and films for } \\
\text { tissue engineering }\end{array}$ & Biocompatible material & (97) \\
\hline Bovine elastin & PNPHO & $\begin{array}{l}\text { Crosslinked } \\
\text { hydrogel } \\
\text { succinimide }\end{array}$ & $\begin{array}{l}\text { Thermoresponsive } \\
\text { hydrogel }\end{array}$ & $\begin{array}{l}\text { High compression moduli, } \\
\text { stable in physiological } \\
\text { conditions, bioabsorbable, cell } \\
\text { encapsulation for at least } 5 \\
\text { days. }\end{array}$ & (98) \\
\hline Bovine elastin & - & $\begin{array}{l}\text { Crosslinked } \\
\text { hydrogel with } \\
\text { hexamethylene } \\
\text { diisocyanate }\end{array}$ & $\begin{array}{l}\text { Hydrogel for tissue } \\
\text { engineering }\end{array}$ & $\begin{array}{l}\text { High porosity that induced the } \\
\text { cellular penetration and growth } \\
\text { throughout the matrices }\end{array}$ & (99) \\
\hline Bovine elastin & - & $\begin{array}{l}\text { Crosslinked } \\
\text { hydrogel with } \\
\text { glutaraldehyde }\end{array}$ & $\begin{array}{l}\text { Hydrogel for tissue } \\
\text { engineering }\end{array}$ & $\begin{array}{lr}\text { High porosity, } & \text { tortuosity } \\
\text { facilitated fibroblast } & \text { penetration and proliferation }\end{array}$ & $(100)$ \\
\hline
\end{tabular}

\section{ELASTIN-LIKE PROTEIN-BASED BIOMATERIALS}

Polymers science has revealed that macromolecules can be excellent candidates to create highly functional biomaterials. Many macromolecules have specific applied functionality, such as the ability to selfassemble, definite recognition, and monodispersity. These features are found enhanced in protein-based biomaterials, and they are based on a complex and strictly defined primary structure $(101,102)$.
In nature, living cells conduct the protein biosynthesis with complete control of the amino acid sequence, from the first amino acid to the last without randomness (102). Therefore, a basic understanding of amino acid-based peptides is the basis for the current development of peptide-based biomaterials. Many features of elastin-like molecules can be controlled through protein engineering, including amino acid sequence, peptide length, or even block polymer when it is desirable (103). It is for the above that peptides 
and high molecular weight polypeptides are emerging as a new class of biomaterials because of their unique chemical, physical, and biological properties. Concerning this, elastin has been used in the biomaterials field in different presentations, including decellularized matrices from various sources (autografts, allografts, and xenografts) and purified preparations. Moreover, insoluble elastin may also be hydrolyzed to obtain soluble elastin preparations, whereas repeated elastin-like sequences can be produced by synthetic or recombinant methods (103).

The development of recombinant DNA technologies to obtain recombinant protein-based polymers has brought the explosion of new peptidebased materials; these polymers are known as recombinamers (104). These materials have functionalities that can be designed in a precise method with selected and advanced properties, such as the integration of selected exogenous bioactivities to develop polymers for cutting-edge in tissue engineering approaches (105).

The basic structure of elastin-like recombinamers (ELRs) involves a repeating sequence based on the recurring steps found in the mammalian elastin (106), drawn on a heterologous host (mainly Escherichia coli) $(107,108)$. The biosynthesis of any artificial protein generally includes: (1) the building of a synthetic gene that encodes the protein of interest in a plasmid; (2) the cloning of a recombinant gene with the necessary transcriptional regulatory elements into competent cells; (3) the screening of plasmids containing the desired clones and verification of their DNA sequence; (4) transformation of the chosen plasmids into expression competent host microorganism; (5) the growth of appropriate volumes of host microorganism and induction of protein expression; and (6) purification of the protein of interest from host lysates (109).

The importance of ELRs resides in that these macromolecules exhibit a broad range of interesting properties that are not easily found simultaneously in other polymers, including stimuli-responsive behavior and the ability to self-assemble (102). These features are present because of a molecular transition of the polypeptide chain in the presence of water at temperatures above a certain level; this is the transition temperature $T_{t}$. The $T_{t}$ of polymers structures based on (Val-Pro-Gly-X-Gly)n like elastin could be controlled by the amino acid at the $\mathrm{X}$ position; this position modifies parameters in the macromolecule like electrochemical potential (110).
Detailed investigations about the influence of polymer microstructure on physical performance, mechanical behavior, and rheological properties are being conducted with regards to the potential impact in tissue engineering applications. Some investigations demonstrate the possible use of the ELRs as materials to construct resolutive cell-laden tissue matrices. These materials provide an ECM-like environment sufficient to induce cell proliferation and differentiation (111). Another approach has proposed a hybrid cell-scaffold for vascular application made of poly-L-lactic acid/poly(D-lactide-co-glycolide) treated with tropoelastin, where the morphology, expansion, and maturity of the newly formed vessels were examined. The results indicated that the elastintreated scaffolds developed more vascularization in comparison to the untreated. Moreover, implantation of tropoelastin-treated scaffolds into mouse abdominal muscle resulted in enhanced perfusion of the penetrating vasculature and improved integration (112). Similar approaches provided further evidence of the benefits of the hybrids ELRs-based-materials, such as blended biomaterials made from tropoelastin and silk fibroin with an adequate mechanical and biological performance (113).

Another method to modify the biomaterial features is changing the composition of a complete protein block, as was done in elastin-mimetic protein block copolymers changing the hydrophobic end block sequences and the hydrophilic block. Some examples of this are in hydrogels materials, which can be obtained by aggregation between the hydrophobic segments of multiblock ELR copolymers. Some studies suggest that the resulting amphiphilic blocks are stable in vivo. Furthermore, it is common to find protein polymers characterized by alternating blocks of hydrophilic and hydrophobic amino acids $(114,115)$.

\section{CONCLUSION AND PERSPECTIVES}

In this article, we summarized the most recent advances in elastin-based biopolymers as biomaterials for tissue engineering applications. Proteins are indispensable for the correct functioning of all the organisms, and elastin accomplishes an essential function in numerous tissues of being humans. Besides its crucial biological role, elastin and its derivated peptides have exhibited a high potential as biomaterials for wound healing, drug delivery, and tissue engineering. A proof of the above is the significant amount of current investigations utilizing 
these biopolymers to manufacture scaffolds and hydrogels for medical purposes. Notably, the mixture of elastin with other biopolymers such as collagen has shown promising results in the fabrication of biopharmaceutical products. Likewise, recent technologies allowed to develop ELPs and ELRs, which may possess a variety of functions and properties present in any natural peptide. Moreover, these functional peptides can self-assemble; thus, they can be mixed with other materials to improve the efficacy of virtually any biomedical device.

However, despite the enormous potential of current technologies, these have generated high expectations and goals that have not been entirely achieved in tissue engineering. A possible explanation for this lack of satisfaction is the difficulty of mimicking the complex environment of human organs. Therefore, existing elastin-based systems can still be improved. In this context, new developments will need to be thoroughly tested in vivo to optimize their physicochemical characteristics and maximize their therapeutic effects.

\section{ACKNOWLEDGMENTS}

This research was funded by CONACYT A1-S-15759 to Gerardo Leyva-Gómez. David Giraldo-Gomez acknowledges to Ana Karen Martínez Ortiz and Ivonne Grisel Sanchez Cervantes from the Microscopy Core Facility of the School of Medicine at the UNAM for their technical assistance with microscopy images of decellularized samples. This research received financial support provided by Dirección General de Asuntos del Personal Académico from the Universidad Nacional Autónoma de México (DGAPA-UNAM) through the Programa de Apoyo a Proyectos de Investigación e Innovación Tecnológica (PAPIIT); project grant: PAPIIT-TA200520.

\section{INTEREST CONFLICT}

The authors declare no conflict of interest

\section{REFERENCES}

1. Yadav P, Yadav H, Shah VG, Shah G, Dhaka G. Biomedical Biopolymers, their Origin and Evolution in Biomedical Sciences: A Systematic Review. J Clin Diagn Res 2015;9:ZE21-5. https://doi.org/10.7860/JCDR/2015/13907.6565.

2. Guadarrama-Acevedo MC, Mendoza-Flores RA, Del Prado-Audelo ML, Urbán-Morlán Z, Giraldo-Gomez
DM, Magaña JJ, et al. Development and evaluation of alginate membranes with curcumin-loaded nanoparticles for potential wound-healing applications. Pharmaceutics 2019;11. https://doi.org/10.3390/pharmaceutics11080389.

3. Cortes H, Caballero-Floran I, Mendoza-Muñoz N, Cordova-Villanueva E, Escutia-Guadarrama L, Figueroa-Gonzalez $G$, et al. Hyaluronic acid in wound dressings. Cell Mol Biol 2020;66:1-8. https://doi.org/http://dx.doi.org/10.14715/cmb/2020. 66.4.23.

4. Cortes H, Caballero-Floran I, Mendoza-Muñoz N, Escutia-Guadarrama L, Figueroa-Gonzalez G, Reyes-Hernandez O, et al. Xanthan gum in drug release. Cell Mol Biol 2020;66:1-9. https://doi.org/http://dx.doi.org/10.14715/cmb/2020. 66.4.24.

5. Nagarajan S, Radhakrishnan S, Kalkura SN, Balme S, Miele P, Bechelany M. Overview of Protein-Based Biopolymers for Biomedical Application. Macromol Chem Phys 2019;220:1900126. https://doi.org/10.1002/macp.201900126.

6. Debelle L, Alix AJP. The structures of elastins and their function. Biochimie 1999;81:981-94. https://doi.org/10.1016/S0300-9084(99)00221-7.

7. Almine JF, Wise SG, Weiss AS. Elastin signaling in wound repair. Birth Defects Res Part C - Embryo Today Rev 2012;96:248-57. https://doi.org/10.1002/bdrc.21016.

8. Karnik SK, Brooke BS, Bayes-Genis A, Sorensen L, Wythe JD, Schwartz RS, et al. A critical role for elastin signaling in vascular morphogenesis and disease. Development 2003;130:411-23. https://doi.org/10.1242/dev.00223.

9. Mochizuki S, Brassart B, Hinek A. Signaling Pathways Transduced through the Elastin Receptor Facilitate Proliferation of Arterial Smooth Muscle Cells. J Biol Chem 2002;277:44854-63. https://doi.org/10.1074/jbc.M205630200.

10. Kowalczyk T, Hnatuszko-Konka K, Gerszberg A, Kononowicz AK. Elastin-like polypeptides as a promising family of genetically-engineered protein based polymers. World J Microbiol Biotechnol 2014;30:2141-52. https://doi.org/10.1007/s11274014-1649-5.

11. Huang W, Rollett A, Kaplan D. Silk-elastin-like protein biomaterials for the controlled delivery of therapeutics. Expert Opin Drug Deliv 2015;12:77991. https://doi.org/10.1016/j.physbeh.2017.03.040.

12. Saxena R, Nanjan MJ. Elastin-like polypeptides and their applications in anticancer drug delivery systems: A review. Drug Deliv 2015;22:156-67. https://doi.org/10.3109/10717544.2013.853210. 
13. Rodríguez-Cabello JC, Arias FJ, Rodrigo MA, Girotti A. Elastin-like polypeptides in drug delivery. Adv Drug Deliv Rev 2016;97:85-100. https://doi.org/10.1016/j.addr.2015.12.007.

14. Demircan M, Cicek T, Yetis MI. Preliminary results in single-step wound closure procedure of fullthickness facial burns in children by using the collagen-elastin matrix and review of pediatric facial burns. Burns 2015;41:1268-74. https://doi.org/10.1016/j.burns.2015.01.007.

15. Rodríguez-Cabello JC, González de Torre I, IbañezFonseca A, Alonso M. Bioactive scaffolds based on elastin-like materials for wound healing. Adv Drug Deliv Rev 2018;129:118-33. https://doi.org/10.1016/j.addr.2018.03.003.

16. Hussain Z, Thu HE, Shuid AN, Katas H, Hussain F. Recent Advances in Polymer-based Wound Dressings for the Treatment of Diabetic Foot Ulcer: An Overview of State-of-the-art. Curr Drug Targets 2018;19:527-50.

https://doi.org/10.2174/13894501186661707041325 23.

17. Rnjak-Kovacina J, Wise SG, Li Z, Maitz PKM, Young CJ, Wang Y, et al. Electrospun synthetic human elastin:collagen composite scaffolds for dermal tissue engineering. Acta Biomater 2012;8:3714-22.

https://doi.org/https://doi.org/10.1016/j.actbio.2012. 06.032 .

18. Kumar VA, Caves JM, Haller CA, Dai E, Liu L, Grainger S, et al. Acellular vascular grafts generated from collagen and elastin analogs. Acta Biomater 2013;9:8067-74.

https://doi.org/https://doi.org/10.1016/j.actbio.2013. 05.024 .

19. Han J, Lazarovici P, Pomerantz C, Chen X, Wei Y, Lelkes PI. Co-Electrospun Blends of PLGA, Gelatin, and Elastin as Potential Nonthrombogenic Scaffolds for Vascular Tissue Engineering. Biomacromolecules 2011;12:399-408. https://doi.org/10.1021/bm101149r.

20. Bealer EJ, Kavetsky K, Dutko S, Lofland S, Hu X. Protein and polysaccharide-based magnetic composite materials for medical applications. Int J Mol Sci 2020;21. https://doi.org/10.3390/ijms21010186.

21. Mithieux SM, Weiss AS. Elastin. Adv Protein Chem 2006;70:437-61. https://doi.org/10.1016/S00653233(04)70013-3.

22. Kristensen JH, Karsdal MA. Elastin. Biochem. Collagens, Laminins Elastin, Elsevier Inc.; 2016, p. 197-201. https://doi.org/10.1016/B978-0-12809847-9.00030-1.
23. Wise BSG, Mithieux SM, Weiss AS. Engineered tropoelastin and elastin-based biomaterials. Adv Protein Chem Struct Biol 2009;78:1-24. https://doi.org/10.1016/S1876-1623(08)78001-5.

24. Olsen BR. Matrix molecules and their ligands. Fourth Edi. Elsevier; 2013. https://doi.org/10.1016/B978-012-398358-9.00010-0.

25. Jaques A, Serafini-Fracassini A. Morphogenesis of the Elastic Fiber: An lmmunoelectronmicroscopy Investigation. J Ultrastruct Res 1985;92:201-10. https://doi.org/https://doi.org/10.1016/08891605(85)90047-3.

26. Scandolera A, Odoul L, Salesse S, Guillot A, Blaise $\mathrm{S}$, Kawecki C, et al. The Elastin Receptor Complex : A Unique Matricellular Receptor with High Antitumoral Potential 2016;7:1-10. https://doi.org/10.3389/fphar.2016.00032.

27. Miao M, Reichheld SE, Muiznieks LD, Huang Y, Keeley FW. Elastin Binding Protein and FKBP65 Modulate in Vitro Self-Assembly of Human Tropoelastin. Biochemistry 2013;52:7731-41. https://doi.org/https://doi.org/10.1021/bi400760f.

28. Yeo GC, Keeley FW, Weiss AS. Coacervation of tropoelastin. Adv Colloid Interface Sci 2011;167:94103. https://doi.org/10.1016/j.cis.2010.10.003.

29. Kaushik P, Rawat K, Bohidar HB. Heat-induced coacervation of elastin and its possible thermoreversibility. Colloid Polym Sci 2019;297:947-56.

https://doi.org/https://doi.org/10.1007/s00396-01904518-1.

30. Aaron BB, Gosline JM. Elastin as a RandomNetwork Elastomer: A Mechanical and Optical Analysis of Single Elastin Fibers 1981;20:1247-60. https://doi.org/https://doi.org/10.1002/bip.1981.360 200611.

31. Koenders MMJF, Yang L, Wismans RG, Werf KO Van Der, Reinhardt DP, Daamen W, et al. Biomaterials Microscale mechanical properties of single elastic fibers: The role of fibrillin microfibrils. Biomaterials 2009;30:2425-32. https://doi.org/10.1016/j.biomaterials.2009.01.038.

32. Muiznieks LD, Keeley FW. Molecular assembly and mechanical properties of the extracellular matrix: A fibrous protein perspective. Biochim Biophys Acta Mol Basis Dis 2013;1832:866-75. https://doi.org/10.1016/j.bbadis.2012.11.022.

33. Li B, Alonso DO V, Bennion BJ, Daggett V. Hydrophobic Hydration Is an Important Source of Elasticity in Elastin-Based Biopolymers. J Am Chem Soc 2001;123:11991-8. https://doi.org/10.1021/ja010363e. 
34. Cox TR, Erler JT. Remodeling and homeostasis of the extracellular matrix: Implications for fibrotic diseases and cancer. DMM Dis Model Mech 2011;4:165-78.

https://doi.org/10.1242/dmm.004077.

35. Dennerlein $\mathbf{J}$ et al TECJSS. Towards Integrating Extracellular Matrix and Immunological Pathways. Cytokine 2017;98:79-86. https://doi.org/10.1016/j.physbeh.2017.03.040.

36. Bellon G, Martiny L, Robinet A. Matrix metalloproteinases and matrikines in angiogenesis. Crit Rev Oncol Hematol 2004;49:203-20. https://doi.org/10.1016/j.critrevonc.2003.10.004.

37. Maquart FX, Pasco S, Ramont L, Hornebeck W, Monboisse JC. An introduction to matrikines: Extracellular matrix-derived peptides which regulate cell activity - Implication in tumor invasion. Crit Rev Oncol Hematol 2004;49:199-202. https://doi.org/10.1016/j.critrevonc.2003.06.007.

38. Duca L, Floquet N, Alix AJP, Haye B, Debelle L. Elastin as a matrikine. Crit Rev Oncol Hematol 2004;49:235-44.

https://doi.org/10.1016/j.critrevonc.2003.09.007.

39. Antonicelli F, Bellon G, Debelle L, Hornebeck W. Elastin-Elastases and Inflamm-Aging. Curr Top Dev Biol 2007;79:99-155. https://doi.org/10.1016/S0070-2153(06)79005-6.

40. Heinz A, Taddese S, Sippl W, Neubert RHH, Schmelzer CEH. Insights into the degradation of human elastin by matrilysin-1. Biochimie 2011;93:187-94.

https://doi.org/10.1016/j.biochi.2010.09.011.

41. Le Page A, Khalil A, Vermette P, Frost EH, Larbi A, Witkowski JM, et al. The role of elastin-derived peptides in human physiology and diseases. Matrix Biol 2019;84:81-96. https://doi.org/10.1016/j.matbio.2019.07.004.

42. Liu Y, Su G, Zhou F, Zhang J, Zheng L, Zhao M. Protective Effect of Bovine Elastin Peptides against Photoaging in Mice and Identification of Novel Antiphotoaging Peptides. J Agric Food Chem 2018;66:10760-8.

https://doi.org/10.1021/acs.jafc.8b04676.

43. Qin Z. Soluble elastin peptides in cardiovascular homeostasis: Foe or ally. Peptides 2015;67:64-73. https://doi.org/10.1016/j.peptides.2015.03.006.

44. Fulop T, Khalil A, Larbi A. The role of elastin peptides in modulating the immune response in aging and age-related diseases. Pathol Biol 2012;60:28-33. https://doi.org/10.1016/j.patbio.2011.10.006.

45. Szychowski KA, Wójtowicz AK, Gmiński J. Impact of Elastin-Derived Peptide VGVAPG on Matrix Metalloprotease-2 and -9 and the Tissue Inhibitor of
Metalloproteinase-1, -2, -3 and -4 mRNA Expression in Mouse Cortical Glial Cells In Vitro. Neurotox Res 2019;35:100-10. https://doi.org/10.1007/s12640018-9935-x.

46. Duca L, Blanchevoye C, Cantarelli B, Ghoneim C, Dedieu S, Delacoux F, et al. The elastin receptor complex transduces signals through the catalytic activity of its Neu-1 subunit. J Biol Chem 2007;282:12484-91.

https://doi.org/10.1074/jbc.M609505200.

47. Daamen WF, Quaglino D. Signaling pathways in elastic tissues. Cell Signal 2019;63:109364. https://doi.org/10.1016/j.cellsig.2019.109364.

48. Robinet A, Millart H, Oszust F, Hornebeck W, Bellon G. Binding of elastin peptides to S-Gal protects the heart against ischemia/reperfusion injury by triggering the RISK pathway. FASEB J 2007;21:1968-78. https://doi.org/10.1096/fj.06$6477 \mathrm{com}$.

49. Gayral S, Garnotel R, Castaing-Berthou A, Blaise S, Fougerat A, Berge E, et al. Elastin-derived peptides potentiate atherosclerosis through the immune Neu1PI3K $\gamma$ pathway. Cardiovasc Res 2014;102:118-27. https://doi.org/10.1093/cvr/cvt336.

50. Kawecki C, Bocquet O, Schmelzer CEH, Heinz A, Ihling $\mathrm{C}$, Wahart $\mathrm{A}$, et al. Identification of CD36 as a new interaction partner of membrane NEU1: potential implication in the pro-atherogenic effects of the elastin receptor complex. Cell Mol Life Sci 2019;76:791-807. https://doi.org/10.1007/s00018018-2978-6.

51. Blaise S, Romier B, Kawecki C, Ghirardi M, Rabenoelina F, Baud S, et al. Elastin-derived peptides are new regulators of insulin resistance development in mice. Diabetes 2013;62:3807-16. https://doi.org/10.2337/db13-0508.

52. Lapis K, Tímár J. Role of elastin-matrix interactions in tumor progression. Semin Cancer Biol 2002;12:209-17. https://doi.org/10.1016/S1044.

53. Romier B, Ivaldi C, Sartelet H, Heinz A, Schmelzer $\mathrm{CEH}$, Garnotel R, et al. Production of elastin-derived peptides contributes to the development of nonalcoholic steatohepatitis. Diabetes 2018;67:1604-15. https://doi.org/10.2337/db170490.

54. Chung AWY, Au Yeung K, Sandor GGS, Judge DP, Dietz HC, Van Breemen C. Loss of elastic fiber integrity and reduction of vascular smooth muscle contraction resulting from the upregulated activities of matrix metalloproteinase- 2 and -9 in the thoracic aortic aneurysm in Marfan syndrome. Circ Res 2007;101:512-22.

https://doi.org/10.1161/CIRCRESAHA.107.157776. 
55. Wanga S, Hibender S, Ridwan Y, van Roomen C, Vos M, van der Made I, et al. Aortic microcalcification is associated with elastin fragmentation in Marfan syndrome. J Pathol 2017;243:294-306.

https://doi.org/10.1002/path.4949.

56. Wen Q, Mithieux SM, Weiss AS. Elastin Biomaterials in Dermal Repair. Trends Biotechnol 2020;38:280-91.

https://doi.org/10.1016/j.tibtech.2019.08.005.

57. Fang S, Riber SS, Hussein K, Ahlmann AH, Harvald EB, Khan F, et al. Decellularized human umbilical artery: Biocompatibility and in vivo functionality in sheep carotid bypass model. Mater Sci Eng C 2020;112:110955.

https://doi.org/10.1016/j.msec.2020.110955.

58. Manji RA, Lee W, Cooper DKC. Xenograft bioprosthetic heart valves: Past, present and future. Int J Surg 2015;23:280-4. https://doi.org/https://doi.org/10.1016/j.ijsu.2015.07. 009.

59. Srokowski EM, Woodhouse KA. Decellularized Scaffolds. Elsevier Ltd.; 2011. https://doi.org/10.1016/B978-0-08-055294-1.000787.

60. Giraldo-Gomez DM, Leon-Mancilla B, Del PradoAudelo ML, Sotres-Vega A, Villalba-Caloca J, Garciadiego-Cazares D, et al. Trypsin as enhancement in cyclical tracheal decellularization: Morphological and biophysical characterization. Mater Sci Eng C 2016;59:930-7. https://doi.org/10.1016/j.msec.2015.10.094.

61. Giraldo-Gomez DM, García-López SJ, Tamay-deDios L, Sánchez-Sánchez R, Villalba-Caloca J, Sotres-Vega A, et al. Fast cyclical-decellularized trachea as a natural 3D scaffold for organ engineering. Mater Sci Eng C 2019;105:110142. https://doi.org/10.1016/j.msec.2019.110142.

62. Kim BS, Kwon YW, Kong J-S, Park GT, Gao G, Han $\mathrm{W}$, et al. 3D cell printing of in vitro stabilized skin model and in vivo pre-vascularized skin patch using tissue-specific extracellular matrix bioink: A step towards advanced skin tissue engineering. Biomaterials 2018;168:38-53. https://doi.org/https://doi.org/10.1016/j.biomaterials. 2018.03.040.

63. Crapo PM, Gilbert TW, Badylak SF. An overview of tissue and whole organ decellularization processes. Biomaterials 2011;32:3233-43. https://doi.org/https://doi.org/10.1016/j.biomaterials. 2011.01.057.

64. Meyer DE, Chilkoti A. Purification of recombinant proteins by fusion with thermally-responsive polypeptides. Nat Biotechnol 1999;17:1112-5. https://doi.org/10.1038/15100.

65. Conticello VP, Carpenter Desai HE. Elastins. vol. 9. 2012. https://doi.org/10.1016/B978-0-444-533494.00248-X.

66. Koens MJW, Faraj KA, Wismans RG, Van Der Vliet JA, Krasznai AG, Cuijpers VMJI, et al. Controlled fabrication of triple layered and molecularly defined collagen/elastin vascular grafts resembling the native blood vessel. Acta Biomater 2010;6:4666-74. https://doi.org/10.1016/j.actbio.2010.06.038.

67. Minardi S, Taraballi F, Wang X, Cabrera FJ, Van Eps $\mathrm{JL}$, Robbins AB, et al. Biomimetic collagen/elastin meshes for ventral hernia repair in a rat model. Acta Biomater 2017;50:165-77. https://doi.org/10.1016/j.actbio.2016.11.032.

68. Annabi N, Fathi A, Mithieux SM, Weiss AS, Dehghani F. Fabrication of porous PCL/elastin composite scaffolds for tissue engineering applications. J Supercrit Fluids 2011;59:157-67. https://doi.org/10.1016/j.supflu.2011.06.010.

69. Annabi N, Fathi A, Mithieux SM, Martens P, Weiss AS, Dehghani F. The effect of elastin on chondrocyte adhesion and proliferation on poly ( $\varepsilon^{-}$ caprolactone)/elastin composites. Biomaterials 2011;32:1517-25.

https://doi.org/10.1016/j.biomaterials.2010.10.024.

70. Buttafoco L, Kolkman NG, Engbers-Buijtenhuijs P, Poot AA, Dijkstra PJ, Vermes I, et al. Electrospinning of collagen and elastin for tissue engineering applications. Biomaterials 2006;27:72434.

https://doi.org/10.1016/j.biomaterials.2005.06.024.

71. McClure MJ, Simpson DG, Bowlin GL. Tri-layered vascular grafts composed of polycaprolactone, elastin, collagen, and silk: Optimization of graft properties. J Mech Behav Biomed Mater 2012;10:48-61.

https://doi.org/10.1016/j.jmbbm.2012.02.026.

72. Fiorica C, Palumbo FS, Pitarresi G, Allegra M, Puleio R, Giammona G. Hyaluronic acid and $\alpha$ elastin based hydrogel for three dimensional culture of vascular endothelial cells. J Drug Deliv Sci Technol 2018;46:28-33. https://doi.org/10.1016/j.jddst.2018.04.017.

73. Skopinska-wisniewska J, Kuderko J, Bajek A, Maj M, Sionkowska A, Ziegler-borowska M. Collagen / elastin hydrogels cross-linked by squaric acid. Mater Sci Eng C 2016;60:100-8. https://doi.org/10.1016/j.msec.2015.11.015.

74. Minardi S, Guo M, Zhang X, Luo X. An elastinbased vasculogenic scaffold promotes marginal islet mass engraftment and function at an extrahepatic 
site. J Immunol Regen Med 2019;3:1-12. https://doi.org/10.1016/j.regen.2018.12.001.

75. Chen Q, Bruyneel A, Carr C, Czernuszka J. Biomechanical properties of novel bi-layer collagenelastin scaffolds for heart valve tissue engineering. Procedia Eng 2013;59:247-54. https://doi.org/10.1016/j.proeng.2013.05.118.

76. Bax D V., Smalley HE, Farndale RW, Best SM, Cameron RE. Cellular response to collagen-elastin composite materials. Acta Biomater 2019;86:15870. https://doi.org/10.1016/j.actbio.2018.12.033.

77. Ryan AJ, O'Brien FJ. Insoluble elastin reduces collagen scaffold stiffness, improves viscoelastic properties, and induces a contractile phenotype in smooth muscle cells. Biomaterials 2015;73:296-307. https://doi.org/10.1016/j.biomaterials.2015.09.003.

78. Grover CN, Cameron RE, Best SM. Investigating the morphological, mechanical and degradation properties of scaffolds comprising collagen, gelatin and elastin for use in soft tissue engineering. J Mech Behav Biomed Mater 2012;10:62-74. https://doi.org/10.1016/j.jmbbm.2012.02.028.

79. Vasconcelos A, Gomes AC, Cavaco-Paulo A. Novel silk fibroin/elastin wound dressings. Acta Biomater 2012;8:3049-60.

https://doi.org/10.1016/j.actbio.2012.04.035.

80. Daamen WF, Van Moerkerk HTB, Hafmans T, Buttafoco L, Poot AA, Veerkamp JH, et al. Preparation and evaluation of molecularly-defined collagen-elastin-glycosaminoglycan scaffolds for tissue engineering. Biomaterials 2003;24:4001-9. https://doi.org/10.1016/S0142-9612(03)00273-4.

81. Daamen WF, Nillesen STM, Hafmans T, Veerkamp JH, Van Luyn MJA, Van Kuppevelt TH. Tissue response of defined collagen-elastin scaffolds in young and adult rats with special attention to calcification. Biomaterials 2005;26:81-92. https://doi.org/10.1016/j.biomaterials.2004.02.011.

82. Kuo YC, Chung CY. Chondrogenesis in scaffolds with surface modification of elastin and poly-1lysine. Colloids Surfaces B Biointerfaces 2012;93:85-91.

https://doi.org/10.1016/j.colsurfb.2011.12.011.

83. Lyu SR, Kuo YC, Ku HF, Hsieh WH. Cryopreserved chondrocytes in porous biomaterials with surface elastin and poly-1-lysine for cartilage regeneration. Colloids Surfaces B Biointerfaces 2013;103:304-9. https://doi.org/10.1016/j.colsurfb.2012.11.002.

84. Kuo YC, Ku HF, Rajesh R. Chitosan $/ \gamma-$ poly(glutamic acid) scaffolds with surface-modified albumin, elastin and poly-L-lysine for cartilage tissue engineering. Mater Sci Eng C 2017;78:265-77. https://doi.org/10.1016/j.msec.2017.04.067.
85. Chong C, Wang Y, Fathi A, Parungao R, Maitz PK, Li Z. Skin wound repair: Results of a pre-clinical study to evaluate electropsun collagen-elastin-PCL scaffolds as dermal substitutes. Burns 2019;45:163948. https://doi.org/10.1016/j.burns.2019.04.014.

86. McClure MJ, Sell SA, Simpson DG, Walpoth BH, Bowlin GL. A three-layered electrospun matrix to mimic native arterial architecture using polycaprolactone, elastin, and collagen: A preliminary study. Acta Biomater 2010;6:2422-33. https://doi.org/10.1016/j.actbio.2009.12.029.

87. Aguirre-Chagala YE, Altuzar V, León-Sarabia E, Tinoco-Magaña JC, Yañez-Limón JM, MendozaBarrera C. Physicochemical properties of polycaprolactone/collagen/elastin nanofibers fabricated by electrospinning. Mater Sci Eng C 2017;76:897-907.

https://doi.org/10.1016/j.msec.2017.03.118.

88. Wise SG, Byrom MJ, Waterhouse A, Bannon PG, Ng MKC, Weiss AS. A multilayered synthetic human elastin/polycaprolactone hybrid vascular graft with tailored mechanical properties. Acta Biomater 2011;7:295-303.

https://doi.org/10.1016/j.actbio.2010.07.022.

89. Foraida ZI, Kamaldinov T, Nelson DA, Larsen M, Castracane J. Elastin-PLGA hybrid electrospun nanofiber scaffolds for salivary epithelial cell selforganization and polarization. Acta Biomater 2017;62:116-27.

https://doi.org/10.1016/j.actbio.2017.08.009.

90. Smith MJ, White KL, Smith DC, Bowlin GL. In vitro evaluations of innate and acquired immune responses to electrospun polydioxanone-elastin blends. Biomaterials 2009;30:149-59. https://doi.org/10.1016/j.biomaterials.2008.09.019.

91. Smith MJ, McClure MJ, Sell SA, Barnes CP, Walpoth BH, Simpson DG, et al. Suture-reinforced electrospun polydioxanone-elastin small-diameter tubes for use in vascular tissue engineering: A feasibility study. Acta Biomater 2008;4:58-66. https://doi.org/10.1016/j.actbio.2007.08.001.

92. Rnjak J, Li Z, Maitz PKM, Wise SG, Weiss AS. Primary human dermal fibroblast interactions with open weave three-dimensional scaffolds prepared from synthetic human elastin. Biomaterials 2009;30:6469-77. https://doi.org/10.1016/j.biomaterials.2009.08.017.

93. Rnjak-Kovacina J, Wise SG, Li Z, Maitz PKM, Young CJ, Wang Y, et al. Tailoring the porosity and pore size of electrospun synthetic human elastin scaffolds for dermal tissue engineering. Biomaterials 2011;32:6729-36. https://doi.org/10.1016/j.biomaterials.2011.05.065. 
94. Dunphy SE, Bratt JAJ, Akram KM, Forsyth NR, El Haj AJ. Hydrogels for lung tissue engineering: Biomechanical properties of thin collagen-elastin constructs. J Mech Behav Biomed Mater 2014;38:251-9.

https://doi.org/10.1016/j.jmbbm.2014.04.005.

95. Palumbo FS, Pitarresi G, Fiorica C, Rigogliuso S, Ghersi G, Giammona G. Chemical hydrogels based on a hyaluronic acid-graft- $\alpha$-elastin derivative as potential scaffolds for tissue engineering. Mater Sci Eng C 2013;33:2541-9. https://doi.org/10.1016/j.msec.2013.02.015.

96. Annabi N, Mithieux SM, Weiss AS, Dehghani F. Cross-linked open-pore elastic hydrogels based on tropoelastin, elastin and high pressure $\mathrm{CO} 2$. Biomaterials 2010;31:1655-65. https://doi.org/10.1016/j.biomaterials.2009.11.051.

97. Silva R, Singh R, Sarker B, Papageorgiou DG, Juhasz-Bortuzzo JA, Roether JA, et al. Hydrogel matrices based on elastin and alginate for tissue engineering applications. Int $\mathrm{J}$ Biol Macromol 2018;114:614-25.

https://doi.org/10.1016/j.ijbiomac.2018.03.091.

98. Fathi A, Mithieux SM, Wei H, Chrzanowski W, Valtchev P, Weiss AS, et al. Elastin based cell-laden injectable hydrogels with tunable gelation, mechanical and biodegradation properties. Biomaterials 2014;35:5425-35. https://doi.org/10.1016/j.biomaterials.2014.03.026.

99. Annabi N, Mithieux SM, Boughton EA, Ruys AJ, Weiss AS, Dehghani F. Synthesis of highly porous crosslinked elastin hydrogels and their interaction with fibroblasts in vitro. Biomaterials 2009;30:45507. https://doi.org/10.1016/j.biomaterials.2009.05.014.

100. Annabi N, Mithieux SM, Weiss AS, Dehghani F. The fabrication of elastin-based hydrogels using high pressure CO2. Biomaterials 2009;30:1-7. https://doi.org/10.1016/j.biomaterials.2008.09.031.

101. Sarikaya M, Tamerler C, Jen AK-Y, Schulten K, Baneyx F. Molecular biomimetics: nanotechnology through biology. Nat Mater 2003;2:577-85. https://doi.org/10.1038/nmat964.

102. Rnjak-Kovacina J, Daamen WF, Pierna M, Rodríguez-Cabello JC, Weiss AS. Elastin biopolymers. Compr Biomater 2011;2:329-46. https://doi.org/10.1016/b978-0-08-055294-1.000714.

103. Daamen WF, Veerkamp JH, van Hest JCM, van Kuppevelt TH. Elastin as a biomaterial for tissue engineering. Biomaterials 2007;28:4378-98. https://doi.org/10.1016/j.biomaterials.2007.06.025.
104. Rodríguez-Cabello JC, Martín L, Alonso M, Arias FJ, Testera AM. "Recombinamers" as advanced materials for the post-oil age. Polymer (Guildf) 2009;50:5159-69.

https://doi.org/https://doi.org/10.1016/j.polymer.200 9.08.032.

105. Arias FJ, Reboto V, Martín S, López I, RodríguezCabello JC. Tailored recombinant elastin-like polymers for advanced biomedical and nano(bio)technological applications. Biotechnol Lett 2006;28:687-95. https://doi.org/10.1007/s10529006-9045-3.

106. Miao M, Bellingham CM, Stahl RJ, Sitarz EE, Lane CJ, Keeley FW. Sequence and structure determinants for the self-aggregation of recombinant polypeptides modeled after human elastin. J Biol Chem 2003;278:48553-62.

https://doi.org/10.1074/jbc.M308465200.

107. McPherson DT, Morrow C, Minehan DS, Wu J, Hunter E, Urry DW. Production and purification of a recombinant elastomeric polypeptide, G(VPGVG)19-VPGV, from Escherichia coli. Biotechnol Prog 1992;8:347-52. https://doi.org/10.1021/bp00016a012.

108. Ibáñez-Fonseca A, Flora T, Acosta S, RodríguezCabello JC. Trends in the design and use of elastinlike recombinamers as biomaterials. Matrix Biol 2019;84:111-26. https://doi.org/10.1016/j.matbio.2019.07.003.

109. Mi L. Molecular cloning of protein-based polymers. Biomacromolecules https://doi.org/10.1021/bm050158h.

110. Urry DW. Physical Chemistry of Biological Free Energy Transduction As Demonstrated by Elastic Protein-Based Polymers. J Phys Chem B 1997;101:11007-28. https://doi.org/10.1021/jp972167t.

111. Salinas-Fernández $\mathrm{S}$, Santos $\mathrm{M}$, Alonso $\mathrm{M}$, Quintanilla L, Rodríguez-Cabello JC. Genetically engineered elastin-like recombinamers with sequence-based molecular stabilization as advanced bioinks for 3D bioprinting. Appl Mater Today 2020;18:100500.

https://doi.org/https://doi.org/10.1016/j.apmt.2019.1 00500 .

112. Landau S, Szklanny AA, Yeo GC, Shandalov Y, Kosobrodova E, Weiss AS, et al. Tropoelastin coated PLLA-PLGA scaffolds promote vascular network formation. Biomaterials 2017;122:72-82. https://doi.org/10.1016/j.biomaterials.2017.01.015.

113. Aghaei-Ghareh-Bolagh B, Mithieux SM, Hiob MA, Wang Y, Chong A, Weiss AS. Fabricated tropoelastin-silk yarns and woven textiles for diverse 
tissue engineering applications. Acta Biomater 2019;91:112-22.

https://doi.org/https://doi.org/10.1016/j.actbio.2019.

04.029.

114. Fernández-Colino A, Arias FJ, Alonso M, Rodríguez-Cabello JC. Self-Organized ECMMimetic Model Based on an Amphiphilic Multiblock Silk-Elastin-Like Corecombinamer with a Concomitant Dual Physical Gelation Process. Biomacromolecules 2014;15:3781-93. https://doi.org/10.1021/bm501051t.

115. Rodríguez Cabello JC, De Torre IG, Cipriani F, Poocza L. Elastin-like materials for tissue regeneration and repair. In: Barbosa MA, Martins MCL, editors. Pept. Proteins as Biomater. Tissue Regen. Repair, Elsevier Ltd.; 2018, p. 309-27. https://doi.org/10.1016/B978-0-08-100803-4.000127. 